\title{
СКУЛЬПТУРА БУКОВИНИ СЕРЕДИНИ ХХ - ПОЧАТКУ ХХІ СТОЛІТТЯ: ВІД СОЦІАЛІСТИЧНОГО РЕАЛІЗМУ ДО ПОСТМОДЕРНІЗМУ
}

\begin{abstract}
Мета статті полягає в аналізі розвитку скульптури на теренах Буковини від середини XX до початку XXI ст.. Методологія дослідження включає комплексне застосування різноманітних методів: історичного, порівняльного, біографічного, мистецтвознавчого аналізу. Використання перелічених методів дозволяє грунтовно проаналізувати поступ образотворчого мистецтва в регіоні. Наукова новизна отриманих результатів полягає у висвітленні художніх процесів на Буковині, які не знайшли відповідного відображення у науковій літературі, введенні в науковий обіг імен художників та аналізі стилістичних особливостей їхніх творів. Висновки. Дослідження даної теми дозволяє об'єктивно розглянути творчий доробок скульпторів різних поколінь та відмінних мистецьких напрямів, простежити вплив на художні практики соціально-політичної ситуації певного історичного періоду і виявити, які світоглядні принципи та стилістичні тенденції переважали у скульптурі Буковини протягом XX - початку XXI ст.. Розвиток скульптури регіону від середини 1940-их рр. до сьогодення демонструє поступовий відхід від традиційних для радянського мистецтва тематичного спрямування та ілюзорної реалістичності, знеособлення персонажів, зведення їх до поширених штампів до творів з багатошаровістю змістів й неоднозначністю сприйняття. Пошуки таких майстрів, як Володимир Гамаль, Іван Салевич, Святослав Вірста, на початку XXI ст. визначають, як буде розвиватися скульптура та образотворче мистецтво краю в цілому, віддаляючись від робіт, що ґрунтуються на літературних сюжетах та впізнаваних, стандартизованих образах і композиційних схемах, до складної за змістом, побудованої на асоціаціях та мистецьких паралелях, пластики постмодернізму.
\end{abstract}

Ключові слова: скульптура Буковини, соціалістичний реалізм, постмодернізм.

Мищенко Ирина Ивановна, кандидат искусствоведения, доцент, докторант Национальной академии руководящих кадров культуры и искусств

Скульптура Буковины середины XX - начала XXI века: от социалистического реализма до постмодернизма

Цель статьи состоит в анализе развития скульптуры на территории Буковины с середины XX до начала XXI вв.. Методология исследования включает комплексное применение разнообразных методов: исторического, сравнительного, биографического, искусствоведческого анализа. Использование перечисленных методов позволяет основательно проанализировать развитие изобразительного искусства в регионе. Научная новизна полученных результатов заключается в освещении художественных процессов на Буковине, которые не нашли соответствующего отражения в научной литературе, введении в научный оборот имен художников и анализе стилистических особенностей их произведений. Выводы. Исследование данной темы позволяет объективно рассмотреть творчество скульпторов разных поколений и различных художественных направлений, проследить влияние на художественные практики социально-политической ситуации определенного исторического периода и выявить, какие мировоззренческие принципы и стилистические тенденции преобладали в скульптуре Буковины в течение XX - начале XXI вв.. Развитие скульптуры региона с середины 1940-ых гг. до сегодняшнего дня демонстрирует постепенный отход от традиционных для советского искусства тематической ориентации и иллюзорной реалистичности, обезличивания персонажей, сведения их к распространенным штампам к произведениям со множеством смыслов и неоднозначностью восприятия. Поиски таких мастеров, как Владимир Гамаль, Иван Салевич, Святослав Вирста, в начале XXI в. определяют, как будет развиваться скульптура и изобразительное искусство края в целом, удаляясь от работ, основанных на литературных сюжетах и узнаваемых, стандартизированных образах и композиционных схемах, к сложной по содержанию, построенной на ассоциациях и художественных параллелях, пластики постмодернизма.

Ключевые слова: скульптура Буковины, социалистический реализм, постмодернизм.

\footnotetext{
Mishchenko Irina, PhD of Art Studies, Associate Professor, Postdoctoral researcher at the National Academy of Culture and Arts management

Bukovinian sculpture from the middle of the 20th - the beginning of the 21st century: from Socialist Realism to Postmodernism

The purpose of the article is to analyze the development of sculpture on the territory of Bukovina from the middle of the XX century to the beginning of the XXI century. The methodology of the study includes the complex application of various methods: historical, comparative, biographical, and art historical analysis. The use of the above methods allows us to analyze the progress of fine arts in the region thoroughly. The scientific novelty of the obtained results is in the coverage of artistic processes in Bukovina, which have not been adequately reflected in the scientific literature, the introduction of scientific names of artists, and the analysis of stylistic peculiarities of their works. Conclusions. The study of this topic makes it possible to consider objectively the creative work of sculptors of different generations and different artistic preference, to trace the influence of the socio-political situation of a particular historical period on artistic practices and to identify which world view principles and stylistic tendencies prevail in Bukovinian sculpture during the $X X$ - the beginning of the XXI century. The development of the sculptures in the region from the mid-1940s to the present
} 
shows a gradual departure from the traditional for Soviet art thematic direction and illusory realism, depersonalization of the characters, and usage of the common stamps, to works with multilayered content and ambiguity of perception. The search for such masters as Volodymyr Gamal, Ivan Salevych, Svyatoslav Virsta at the beginning of the XXI century determines how the sculpture and fine art of the region will develop in general, moving away from works based on literary plots and recognizable, standardized images and compositional schemes, to the complex content constructed on associations and artistic parallels, postmodernism plastics.

Key words: sculpture of Bukovina, Socialist Realism, Postmodernism.

Актуальність теми дослідження зумовлена тим, що образотворчість Буковини середини XX початку XXI ст. загалом, як і скульптура, зокрема, досі практично не були предметом вивчення науковцями. Лічені праці, присвячені мистецтву краю, здебільшого, висвітлюють розвиток живопису, тож опертися у ході вивчення даної проблеми можна лише на окремі публікації, переважну кількість яких складають проспекти, каталоги, статті у часописах та енциклопедичних виданнях. Зважаючи на це, вивчення скульптури даного періоду є вкрай актуальним з погляду всебічного висвітлення історії українського мистецтва, осмислення художніх процесів сьогодення.

Аналіз досліджень і публікацій свідчить, що зазначена тема не знайшла належного відображення у науковій літературі та недостатньо висвітлена навіть у науково-популярних дописах.

Серед публікацій слід назвати каталоги та проспекти, видані Чернівецькою організацією Спілки художників України, зокрема, укладені Т. Удіною та К. Валігурою [2; 6; 7; 8], котрі, як і видання «Митці Буковини» [9], містять біографічні дані про митців. Винятком є праця Т. Дугаєвої, в якій докладно розглянуто доробок О. Шевчукевича [5].

Творчість сучасних скульпторів частково подана у публікаціях автора цієї статті [3; 10] та каталогах різноманітних проектів [1; 4], у яких вміщено переважно репродукції творів та каталожні дані. Проте, не існує узагальнюючої праці, у якій було б розглянуто поступ пластики регіону, що підтверджує необхідність вивчення цього питання.

Мета дослідження полягає в аналізі шляхів розвитку буковинської скульптури від середини XX до початку XXI ст., виявленні закономірностей стилістичних змін у пластиці регіону. Наукова новизна зумовлена введенням у науковий обіг значної кількості імен і творів скульпторів зазначеного періоду, висвітленням особливостей проявів різноманітних мистецьких напрямів у творчості окремих авторів.

Виклад основного матеріалу. Розвиток скульптури Буковини XX-XXI ст. у більшості своїх проявів повторює етапи та особливості поступу образотворчого мистецтва краю в цілому.

Територію Північної Буковини (нині - Чернівецька обл. України) було приєднано до УРСР внаслідок пакту Молотова-Ріббентропа у 1940 р.. В цей час відбулася зміна генерації художників, оскільки численні випускники знаних європейських мистецьких закладів (а серед чернівецьких майстрів були учні Віденської, Мюнхенської, Празької, Краківської, Берлінської, Флорентійської та Бухарестської академій, відомих приватних студій, зокрема паризької академії Жуліана) змушені були у 1940-1944 рр. виїхати за межі країни. Натомість до Чернівців прибула значна кількість випускників художніх училищ та інститутів СРСР, часто - колишніх фрронтовиків. Уже 1944 р., одразу після звільнення країни від німецьких військ, тут відбулася перша мистецька виставка.

Серед тих, хто приїхав на Буковину протягом 1940-1950-их рр., - скульптори Антоніна Тебенькова (1909-1976), Микола Мірошниченко (1936-2013), Анатолій Скиба (1930-2001). Зі скульпторів дорадянського періоду у Чернівцях продовжував працювати тільки уродженець регіону лікар та художник Опанас Шевчукевич (1902-1972).

Для творчості цих майстрів, які здебільшого працювали у відповідності до вимог мистецтва соціалістичного реалізму, протягом 1950-1970-их рр. характерне звернення до теми Великої Вітчизняної війни, побутового жанру, створення численних портретів діячів історії та культури України й республік СРСР, героїв війни і праці. Винятком стали тільки окремі роботи О. Шевчукевича, які нагадували його власні близькі до стилістики експресіонізму твори 1920-1940-их рр.. Багато хто з перелічених авторів і протягом 1980-2010-их рр., незважаючи на зміну соціально-політичної та мистецької ситуації, продовжував працювати у звичній стилістиці (М. Мірошниченко).

У 1960-1970-их рр. у Чернівцях почали працювати Микола Лисаківський (1943-2010), Юрій Джибраєв (1935 р.н.), Петро Лемський (1936 р.н.), Дмитро Горшковський (1940-2015) та Анатолій Піонтковський (1952 р.н.). Окрім професійних скульпторів, до створення робіт в галузі пластики періодично зверталися й художники іншого фраху, зокрема, Артем Присяжнюк (1947-2017), Іван Вихренко (1939-2004).

Юрій Джибраєв працював у Чернівцях у 1966-1981 рр., створивши меморіальні ансамблі на честь загиблих воїнів та численні портрети, звертаючись до скульптури малих фрорм. Попри спільну для багатьох авторів тематичну складову, роботи художника, передовсім портрети, позначені виразністю цілісних, лаконічно вирішених образів, узагальнені форми та стилістика вирішення яких мають витоки у новаціях монументального мистецтва 1960-их рр..

Значний доробок залишив Микола Лисаківський, серед робіт якого 1980-1990-их рр. пам'ятники Т. Шевченку та воїнам-афганцям, меморіальні дошки акторові І. Миколайчуку, театральному діячеві В. Васильку, композиторові В. Івасюку у Чернівцях. У них автор, здебільшого, послуговується прийомами та фооральними рішеннями, характерними для української скульптури кінця 1960- 
1970-их рр.. Особливо це помітно у пам'ятнику загиблим воїнам-афганцям у Чернівцях, що вирізняється майже франтасмагоричним поєднанням рис провінційних варіацій монументів воїнамвизволителям радянських часів і християнської символіки. Композиція, створена за зразком «Пієти», вирізняється реалістичністю трактування та надмірною деталізацією. Зауважимо, проте, що у конкурсі проектів спорудження цього монументу переміг інший ескіз того ж автора - лаконічно-символічний та цікавіший за художнім вирішенням. Проте, згодом тиск замовника змусив автора використати «зрозуміліший» й водночас стандартний варіант.

В цілому монументальна пластика митця часто видається невиправдано перенасиченою деталями й символами, а подекуди вирізняється й плакатністю вирішення (твір, присвячений Голодомору, меморіальна дошка на честь Андрея Шептицького у Чернівцях, тощо). Дещо іншою за стилістикою постає станкова пластика художника. Камерна за звучанням, вона позначена особливою ліричністю, більшою мірою узагальнення й цілісністю.

Стилістичні зміни у пластиці краю чи не вперше стали помітними у доробку Петра Грицика (1944 р.н.), який працював в галузі кераміки, монументального мистецтва та станкового живопису. В його роботах яскраво виражена естетика постмодернізму з притаманною йому аналітичністю і водночас спонтанністю емоційного вираження, а композиції художника вирізняються знаковістю та високою пластичною культурою.

Працюючи в кераміці від кінця 1960-их до середини 1980-их рр., він створював, здебільшого, цикли робіт, об'єднаних спільною темою або принципом вирішення. Серед них - чотири композиції 3 шамотної маси для їдальні Чернівецької організації Українського товариства сліпих (1987), які складають цілісний ансамбль зі стінним розписом того ж автора. Використовуючи єдиний для всіх пластів прийом - розташування крупних зображень-символів на увігнутій основі, яка увиразнює відчуття просторової глибини, художник творить пластичний образ світу людини, позбавленої зору, коли сприйняття оточення відбувається лише на дотик, що відчуває найтонші зміни рельєфу. Підкреслюючи гранично спрощені силуети відтворених предметів, поєднуючи увігнуті й опуклі об'єми з майже невловимими перепадами висоти, митець досягає ледь не живописної розробки кожної площини, м'яких ефектів освітлення, підсилених стриманим і водночас емоційно напруженим колірним вирішенням, в якому домінують складні брунатно-зелені, сіро-вохристі, блакитно-сірі й сіро-зелені тони.

Відмінною від більшості тогочасних чернівецьких скульпторів стилістикою позначена й творчість випускника Талліннського державного художнього інституту Володимира Гамаля (1948 р.н.). Роботи останнього вирізняються чистотою ліній, виразністю чітких обрисів та вивіреністю силуетів, пластичною свободою і заразом продуманою цілісністю образу, в якому масивні й замкнені геометричні форми поєднуються 3 промовистістю символічних елементів (пам'ятники П. КонашевичуСагайдачному у Хотині, 1991; Ю. Федьковичу у Чернівцях, 1995; композиція «Край», 1988; «Кобзар»; «Mpiï», 2001).

До покоління майстрів, творчий шлях яких розпочався наприкінці 1980-их рр., слід віднести Івана Салевича (1960 р.н.) та Святослава Вірсту (1962 р.н.).

І. Салевич, працюючи на перетині раціонального та асоціативного, традиційних уявлень і гри змістів, експериментуючи на межі різних видів мистецтва, органічно вписується в сучасну мистецьку ситуацію, стаючи часткою постмодерністського простору в Україні, адже прагне створювати навіть не пластичні метафори, а новий вимір реальності.

Використовуючи ремінісценції класичної культури, виконуючи роботи, в яких все підпорядковане формальній виразності, а символ, завдяки своїй ємності, стає найкоротшим шляхом до лаконічності вирішення, скульптор намагається вловити сутність звичних речей, часто саме в них віднаходячи символічний образ. Подекуди навіть стандартна форма предметів дозволяє митцеві візуалізувати неоднозначність часу, надати роботі несподіваної публіцистичності звучання («Каплиця нашого жалю», 1989; «Ситуація», 1991; «Квітка нашої культури», 1990; триптих «Символи України», 1998-2001, «Крісло для українського можновладця», 2015).

Першопоштовхом для мистецьких пошуків І. Салевича наприкінці 1980-их рр. став доробок художників, котрі були втіленням пластичних новацій (О. Архипенка, Г. Мура, О. Цадкіна). Властиве роботам цих скульпторів взаємопроникнення предметної форми і оточення, прагнення сконструювати середовище, в якому власне скульптура підпорядкована єдиному внутрішньо-обумовленому розвитку пластично-просторової ідеї, згодом стане визначальним у більшості робіт цього автора.

Найхарактернішими рисами творів раннього періоду виступатимуть лаконічність цілісного, точно окресленого силуету, подекуди доповненого ритуванням («Єгипетські ремінісценції», 1993), ритмічна виразність композиції, побудованої на співставленні вертикальних та горизонтальних об'ємів («Горе»), або домінанті прямовисного елементу («Молитва», «Народження Венери»). У скульптурі згаданого часу автор часто вдається до поліхромії, надихаючись, зокрема, зразками давньоєгипетської й древньогрецької пластики та застосовуючи розпис («Подолянка», 1988, «Фараон», 1989).

Від кінця 1980-их рр. художник звертається до композицій з розташованих окремо різномасштабних елементів, завдяки чому виникає складний простір, взаємодія пластичних елементів й оточення («Острови мого дитинства», 1988; «Ікар», 1991; «Велика породілля», 1997). Обмежуючи зображен- 
ня невеликою кількістю деталей, митець застосовує несподівані ракурси, загострює фрорми, прагнучи відтворити фізичну й емоційну напругу дії, вдало використовує розмаїття фактур.

Пластично-образну мову робіт відчутно збагачує використання давніх символів (дерева життя, фралічних знаків та ін.), що призводить до утворення візуальних паралелей, варіативності вирішення усталених образів і водночас відбиває складнішу модель світосприйняття («Пустельник», 1991; «Вічне древо», 1998; «Жінка-древо», 2000; «Посвята Опішному», 2000). Від початку 2000-их рр. у станкових роботах І. Салевича значну роль відіграють площинно-графічні елементи та узагальнений силует, а самі твори за вирішенням наближаються до дизайнерських об’єктів («Каріатида сонця», 2004; «Намисто для богині», 2005; «Танець купальської ночі», 2000).

Витонченістю лаконічного й точно знайденого образу вирізняються й виконані митцем монументальні твори, вдало вписані в існуючу архітектурну ситуацію (пам'ятник П. Целану, меморіальні дошки, присвячені диригентові Б. Крижанівському, акторові Б. Боріну, байкареві Е. Штейнбаргу). Чутливість до процесів, що відбуваються в сучасному мистецтві, у творчості художника поєднується 3 логічною послідовністю змін, прояви яких помітні на різних етапах його творчості, засвідчуючи невипадковість торованого ним шляху і впевненість у власних художніх переконаннях.

Для творчості Святослава Вірсти характерне як звернення до архетипів, використання спільних для всього людства найдавніших - ще неолітичної доби символів, прагнення віднайти лаконічну та всеохоплюючу систему понять, збагативши сучасну пластично-образну мову, відійти від реальності, відтворення - до асоціацій, знаковості зображення, так і опрацювання пластичних ідей авангардного мистецтва XX ст.. Саме тому виникають численні ремінісценції скульптури первісної доби («Палеолітична красуня», 1998;, «Баба», 2003; «Володар синіх гір», 2000).

Відмінними за звучанням стали виконані в 1990-их рр. чоловічі постаті. Точно окреслені, замкнені силуети робіт, увиразнені поліхромією й доповнені включенням фрактури, відтворюють то відчуття дієвої творчої енергії («Поет»), то суворої самотності або байдужості («Чоловік в пальті» (1992) та «Відсутній» (1996). У роботах 2000-их рр. помітним стає мотив одинокості («Самота»), а характерні для художника геометризовані фрорми набувають окреслень фронтальної стели, підкреслюючи застиглість людини-каменю, її приреченість на самотність. Протиставлення людини всьому, що її оточує, i частиною чого вона воднораз є, відчутне у творі «Сутінки» (2007). Дещо незвична за просторовим вирішенням робота нагадує умовний краєвид, подані узагальнено заокруглені маси якого можуть бути і позначкою міста, і символом гір або лісу. Тут аморфна маса, що огортає людину, поступово перетворюється на графічну тінь подібної до неї, проте значно більшої за розміром постаті. Таким чином у пластиці виникає досить рідкісне у цьому виді мистецтва зображення пейзажу, об'єднане з актуальною на сьогодні темою єдності й водночас протиставлення індивідуальності та її оточення.

Згодом у пластиці художника, виконаній в різних матеріалах, визначаться два напрямки, що надалі існуватимуть паралельно - перетворення фрігури людини на своєрідний орнамент з підкресленою ритмічністю чітких геометричних елементів та втілення образів-асоціацій, що відбивають певний стан. Це особливо помітно у роботах початку 2000-их рр., де тонкі відтінки емоцій органічно суміщаються із запрограмованою монументальністю вирішення. Ці риси зауважуємо і в нестандартності вирішення композиції «Одинний» («Посвята Миколі Бучкові», 2012), де портрет конкретної людини перетворюється на образ покоління.

Висновки. Розвиток скульптури Буковини від середини 1940-их рр. до сьогодення якнайповніше ілюструють розвиток образотворчості краю, відхід від традиційної для радянського мистецтва удаваної, ілюзорної реалістичності та визначеного кола тем, ілюстративності та літературної основи творів до робіт з багатошаровістю змісту й неоднозначністю сприйняття, трансформацією пластичних ідей класичного мистецтва та мистецтва постмодернізму.

Якщо протягом 1950 - середини 1980-их рр. індивідуальні прояви дещо нівелювалися спільним для різних авторів тематичним спрямуванням творів, певними (й доволі жорсткими) вимогами до пластичного вирішення, то від кінця 1980-их рр. помітним стає не лише розширення тематики робіт, а й розмаїття формальних рішень. Різкий сплеск публіцистичності в скульптурі кінця 1980-их - початку 1990-их рр., зумовлений зміною соціально-політичної ситуації в Україні, згодом поступиться пошуку нетривіальних пластичних ідей.

Показовими в цьому є роботи таких майстрів, як В. Гамаль, І. Салевич, С. Вірста, творчість яких на сьогодні багато в чому визначає те, як буде розвиватися буковинська скульптура, поступово віддаляючись від робіт, що ґрунтуються на літературній основі, до складної за образністю, побудованої на асоціаціях та мистецьких паралелях пластики.

\section{תimepamypa}

1. Меридіан серця / Вст. ст. О. Ягодовська. Чернівці : Букрек, 1998. 40 с.

2. Антоніна Тебенькова : проспект. Чернівці, 1973.

3. Міщенко І. Кераміка у творчості буковинських художників 1980-2000-х років // Студії мистецтвознавчі. 2010. № 2 (30). C. 42-49.

4. Мистецтво Буковини : каталог. Чернівці, 2004. 64 с.

5. Дугаєва Т. Скульптор, доктор медицини Опанас Шевчукевич. Чернівці : Зелена Буковина, 2002. 88 с.

6. Юрій Джибраєв : проспект виставки творів / Авт.-упоряд. Т. Удіна, Є. Удін. Чернівці, 1970. 